\title{
Saccharofermentans acetigenes gen. nov., sp. nov., an anaerobic bacterium isolated from sludge treating brewery wastewater
}

Correspondence Shuangya Chen shuangych@yahoo.com

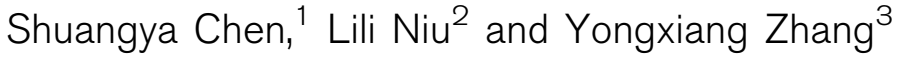 \\ ${ }^{1}$ Laboratory of Microbiology, Xiamen Inspection \& Quarantine Technology Center, Xiamen, 361026, \\ PR China \\ ${ }^{2}$ Shanghai Key Laboratory of Bio-energy Crops, School of Life Sciences, Shanghai University, \\ Shanghai, 200444, PR China \\ ${ }^{3}$ Zhangzhou Inspection \& Quarantine Bureau, Zhangzhou, 363000, PR China
}

Complex organic matter is degraded completely to $\mathrm{CO}_{2}$ and $\mathrm{CH}_{4}$ by the association of several trophic microorganisms in methanogenic environments (Zehnder, 1978). The presence of members of the class Clostridia in brewery wastewater was revealed by $16 \mathrm{~S}$ rRNA gene sequence analysis (Liu et al., 2002). During a survey of the microbial community in sludge treating brewery wastewater in Fujian Province, China, we isolated a novel obligately anaerobic, spore-forming bacterial strain (designated $\mathrm{P}^{\mathrm{T}}$ ). This strain fermented several sugars and produced mainly acetic acid from glucose fermentation. Phylogenetically, the strain was affiliated to clostridial cluster III of the low-G $+\mathrm{C}$ content Gram-positive bacteria (Collins et al., 1994), but was distantly related to all recognized genera and species in this cluster. Based on its distinctive phenotypic, genotypic and phylogenetic characteristics, this strain is shown to represent a novel species of a new genus.

The GenBank/EMBL/DDBJ accession number for the 16S rRNA gene sequence of strain $P 6^{\top}$ is $A Y 949857$.
Strain $\mathrm{P}^{\mathrm{T}}$ was isolated in pre-reduced peptone-yeast extract-glucose (PYG) medium (Holdeman et al., 1977) by serial dilution with the Hungate roll-tube technique (Hungate, 1969). Single colonies were picked and transferred to the same broth and incubated at $37{ }^{\circ} \mathrm{C}$ for 2 days. The rolling tube procedure was repeated several times until a pure culture was obtained. The purity of the isolate was confirmed by the homogeneous morphology of colonies on the agar surface as well as cell type observed by microscopy (see below). Routine cultivation was in anaerobically prepared PYG broth in tubes $(18 \times 150 \mathrm{~mm})$ sealed with butyl rubber stoppers under a gaseous atmosphere of $100 \% \mathrm{~N}_{2}(100 \mathrm{kPa})$ at $37{ }^{\circ} \mathrm{C}$. Acetivibrio cellulolyticus ATCC $33288^{\mathrm{T}}$ was obtained from the American Type Culture Collection. Clostridium aldrichii DSM $6159^{\mathrm{T}}$ and Clostridium thermocellum DSM $1237^{\mathrm{T}}$ were obtained from the Deutsche Sammlung von Mikroorganismen. PY medium plus $1 \%$ cellobiose was used for cultivation of these reference strains.

Cell morphology was examined by light microscopy (Olympus BH-2) as well as electron microscopy (Hitachi 
H-600A) after negative staining with uranyl acetate. Generation time was determined by monitoring $\mathrm{OD}_{600}$ of a PYG broth culture at $37^{\circ} \mathrm{C}$ at $1 \mathrm{~h}$ intervals up to $48 \mathrm{~h}$. Temperature profiles were determined in PYG broth by using a water bath (MEMMERT WB 22) at $15-55{ }^{\circ} \mathrm{C}\left(1{ }^{\circ} \mathrm{C}\right.$ intervals). The $\mathrm{pH}$ range for growth of strain $\mathrm{P}^{\mathrm{T}}$ was determined in PYG broth adjusted to $\mathrm{pH} 4.5-9.5$ with $\mathrm{HCl}$ or $\mathrm{NaOH}(1 \mathrm{M})$. Growth was determined by measuring the $\mathrm{OD}_{600}$ of the cultures at 1,3 and 7 days. Biochemical traits were determined by using both conventional methods and the API 50CH system (bioMérieux). All tests were performed in duplicate. Short-chain fatty acids and gases produced from fermentation in PYG medium were measured by using a gas chromatograph (Shimadzu GC-14B) according to the method described by Chen \& Dong (2004).

Cellular fatty acids were extracted, methylated and analysed by using the standard MIDI (Microbial Identification) system (Miller, 1982; Sasser, 1990). Genomic DNA was extracted and purified as described by Marmur (1961). The $\mathrm{G}+\mathrm{C}$ content of the DNA was determined by thermal denaturation (Marmur \& Doty, 1962) by using a DU800 spectrophotometer (Beckman) with Escherichia coli K-12 as reference.

The 16S rRNA gene of strain $\mathrm{P}^{\mathrm{T}}$ was amplified by PCR and sequenced as described by Chen \& Dong (2004). The $16 \mathrm{~S}$ rRNA gene sequence of strain $\mathrm{P}^{\mathrm{T}}$ was submitted to GenBank to search for similar sequences by using the BLAST algorithm. The most closely matching sequences were retrieved from the database and were aligned by using the ClUSTAL X program (Thompson et al., 1997). Phylogenetic trees were reconstructed via the neighbour-joining, minimum-evolution, UPGMA and maximum-parsimony methods as implemented in the program MEGA2 (Kumar et al., 2001), and the resultant tree topologies were evaluated by bootstrap analysis of 1000 datasets.

Cells of strain $\mathrm{P}^{\mathrm{T}}$ were Gram-positive and oval (0.6-0.9 by $1.2-1.8 \mu \mathrm{m})$. Motility was not observed. Endospores were formed, resulting in swollen cells. Colonies on PYG agar were white, round and translucent, and about $1 \mathrm{~mm}$ in diameter after cultivation at $37{ }^{\circ} \mathrm{C}$ for $48 \mathrm{~h}$.

Strain $\mathrm{P}^{\mathrm{T}}$ grew exclusively in pre-reduced media and growth was completely inhibited by air. It was unable to utilize inorganic nitrogen compounds such as $\mathrm{NH}_{4} \mathrm{Cl}$, $\left(\mathrm{NH}_{4}\right)_{2} \mathrm{SO}_{4},\left(\mathrm{NH}_{4}\right)_{2} \mathrm{HPO}_{4}$ and $\mathrm{KNO}_{3}$ as sole nitrogen source. Yeast extract $(0.2 \%)$ was required for growth. Strain $\mathrm{P}^{\mathrm{T}}$ grew at $20-42{ }^{\circ} \mathrm{C}$ and at $\mathrm{pH} 5.0-7.5$, with optimum growth at $37{ }^{\circ} \mathrm{C}$ and approximately $\mathrm{pH}$ 6.5. Growth was observed in the presence of $0-2 \%(\mathrm{w} / \mathrm{v}) \mathrm{NaCl}$. The mean generation time of strain $\mathrm{P}^{\mathrm{T}}$ was $6.2 \mathrm{~h}$ when grown in PYG broth at $37{ }^{\circ} \mathrm{C}$.

Strain $\mathrm{P}^{\mathrm{T}}$ hydrolysed aesculin but not gelatin, and produced acid from several sugars, such as D-glucose, Dfructose, sucrose, starch, aesculin, adonitol, dulcitol, inositol and mannitol. No acid was produced from cellulose or xylan (detailed data are given in the species description below).
Milk was not curdled. Indole was not produced. Nitrate was not reduced. The main end products of glucose fermentation were acetate, lactate and fumarate; additional trace products including $\mathrm{H}_{2}$ and $\mathrm{CO}_{2}$ were also observed. Strain $\mathrm{P}^{\mathrm{T}}$ did not use sulfate as electron acceptor. $\mathrm{No}_{2} \mathrm{~S}$ was produced from peptone or thiosulfate.

The DNA G + C content of strain $\mathrm{P}^{\mathrm{T}}$ was $55.6 \mathrm{~mol} \%$. The predominant cellular fatty acids were iso- $\mathrm{C}_{15: 0}(24.92 \%)$ and anteiso- $\mathrm{C}_{15: 0}(24.22 \%)$; iso- $\mathrm{C}_{14: 0} 3-\mathrm{OH}(13.77 \%)$, iso- $\mathrm{C}_{14: 0}(4.84 \%)$ and $\mathrm{C}_{16: 0}(4.81 \%)$ were also relatively abundant. This profile differed from those of phylogenetically related species of the genus Clostridium, mesophilic members of this genus being characterized by a higher percentage of unsaturated fatty acids and the absence of branched-chain fatty acids (Kaneda, 1991). It also differed from the thermophilic bacterium C. thermocellum, for which $75 \%$ of the cellular fatty acids were branched.

To ascertain the phylogenetic position of strain $\mathrm{P}^{\mathrm{T}}$, the complete 16S rRNA gene sequence (1510 bp) was compared with the most similar sequences retrieved from GenBank. Phylogenetic analysis showed that strain $\mathrm{P}^{\mathrm{T}}$ could be accommodated in clostridial cluster III of the low$\mathrm{G}+\mathrm{C}$ content Gram-positive bacteria, and that it was related most closely to cloned $16 \mathrm{~S}$ rRNA gene sequences of uncultured bacteria. A phylogenetic tree including strain $\mathrm{P}^{\mathrm{T}}$ and other representatives of clusters III, IV, XIII, II and I in the family Clostridiaceae was reconstructed (Fig. 1), based on a consensus length of $1365 \mathrm{bp}$ of the 16S rRNA gene sequence, and was rooted with Clostridium butyricum ATCC $19398^{\mathrm{T}}$ and Clostridium perfringens ATCC $13124^{\mathrm{T}}$. Treeing analysis showed that strain $\mathrm{P}^{\mathrm{T}}$ and Fastidiosipila sanguinis CCUG $47711^{\mathrm{T}}$ formed a deep branch but were related only distantly ( $87.8 \% \quad 16 \mathrm{~S}$ rRNA gene sequence similarity). Strain $\mathrm{P}^{\mathrm{T}}$ showed highest levels of $16 \mathrm{~S}$ rRNA gene sequence similarity with Clostridium straminisolvens DSM $16021^{\mathrm{T}}(90.0 \%)$, C. thermocellum DSM $1237^{\mathrm{T}}$ (89.8\%), A. cellulolyticus ATCC $33288^{\mathrm{T}}(89.7 \%)$ and C. aldrichii DSM $6159^{\mathrm{T}}(89.7 \%)$; levels of similarity ranged between 87.8 and $88.0 \%$ with the type strains of other related species in cluster III. Bootstrap resampling showed that this relationship was statistically significant (99\% recovery in 1000 resamplings). The high level of sequence divergence indicated that strain $\mathrm{P}^{\mathrm{T}}$ could represent a novel species of a new genus in this cluster.

Strain $\mathrm{P}^{\mathrm{T}}$ also showed distinct phenotypic features that could be used to distinguish it from phylogenetically related members in the same cluster. First, all of its closest relatives, namely C. straminisolvens (Kato et al., 2004), C. thermocellum (McBee, 1954), A. cellulolyticus (Patel et al., 1980) and C. aldrichii (Yang et al., 1990), were cellulolytic bacteria, whereas strain $\mathrm{P}^{\mathrm{T}}$ was a sugar-fermenting bacterium, produced acid from glucose and did not degrade cellulose (Table 1). The DNA G+C content of strain $\mathrm{P}^{\mathrm{T}}$ $(55.6 \mathrm{~mol} \%)$ was far higher than those of related species (38-41.3 mol\%), also suggesting that it belonged to a different genus. Strain $\mathrm{P}^{\mathrm{T}}$ differed from C. straminisolvens 


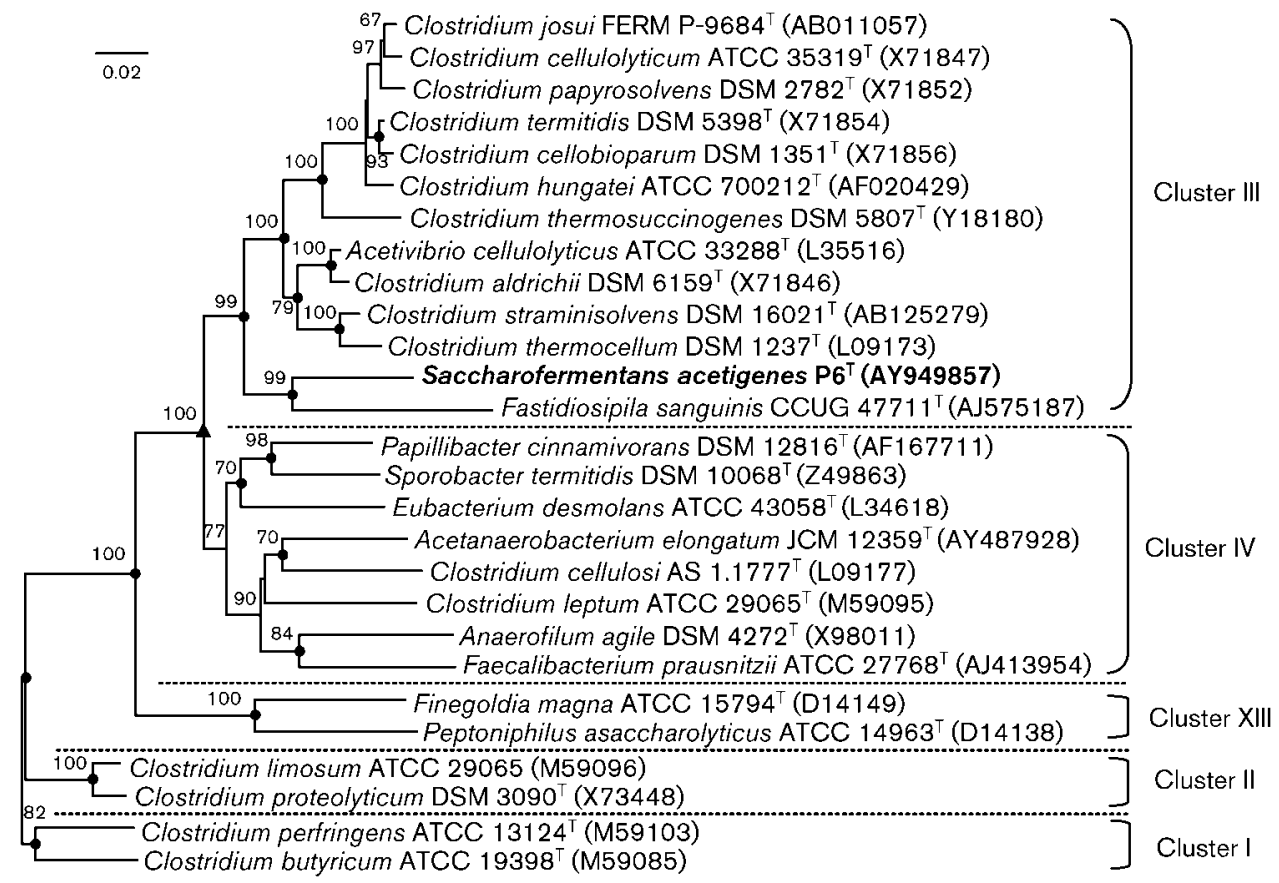

Fig. 1. Neighbour-joining phylogenetic dendrogram showing the position of strain $P 6^{\top}$ among related species based on $16 \mathrm{~S}$ rRNA gene sequences. The tree was rooted with C. butyricum ATCC $19398^{\top}$ and C. perfringens ATCC $13124^{\top}$. Solid circles indicate that the corresponding nodes (groups) were also recovered with the minimum-evolution and maximum-parsimony methods. The solid triangle indicates that the corresponding node was also recovered with the minimum-evolution and UPGMA methods. Numbers at branch points are levels of bootstrap support (\%) based on a neighbour-joining analysis of 1000 resampled datasets. GenBank accession numbers of $16 \mathrm{~S}$ rRNA gene sequences are given in parentheses. Bar, $2 \%$ sequence divergence.

Table 1. Differential characteristics between strain $P 6^{\top}$ and its phylogenetic relatives

Strains: 1, $\mathrm{P}^{\mathrm{T}} ; 2$, Clostridium straminisolvens DSM $16021^{\mathrm{T}} ; 3$, Clostridium thermocellum DSM $1237^{\mathrm{T}} ; 4$, Acetivibrio cellulolyticus ATCC $33288^{\mathrm{T}} ; 5$, Clostridium aldrichii DSM $6159^{\mathrm{T}} ; 6$, Fastidiosipila sanguinis CCUG $47711^{\mathrm{T}}$.

\begin{tabular}{|c|c|c|c|c|c|c|}
\hline Characteristic & 1 & $2^{a}$ & 3 & 4 & 5 & $6^{b}$ \\
\hline \multicolumn{7}{|l|}{ Acid production from: } \\
\hline Glucose & + & - & $-c, d$ & $-^{d, e}$ & $-{ }^{d, f}$ & - \\
\hline Fructose & + & - & $-c, d$ & $-{ }^{d, e}$ & $-{ }^{d, f}$ & - \\
\hline Sucrose & + & - & $-c, d$ & $-{ }^{d, e}$ & $-{ }^{d, f}$ & - \\
\hline Starch & + & - & $-c, d$ & $-{ }^{d, e}$ & $-{ }^{d, f}$ & - \\
\hline Mannitol & + & - & $-c, d$ & $-{ }^{d, e}$ & $-{ }^{d, f}$ & - \\
\hline Cellulose & - & + & $++^{c, d}$ & $+{ }^{d, e}$ & $+{ }^{d, f}$ & - \\
\hline Spore formation & + & + & $++^{c, d}$ & $-{ }^{d, e}$ & $+{ }^{d, f}$ & - \\
\hline $\begin{array}{l}\text { Optimum temperature } \\
\left({ }^{\circ} \mathrm{C}\right)\end{array}$ & 37 & $50-55$ & $60^{c, d}$ & $35^{e}$ & $35^{f}$ & 37 \\
\hline $\begin{array}{l}\text { DNA G + C content } \\
(\mathrm{mol} \%)\end{array}$ & 55.6 & 41.3 & $38^{d}$ & $38^{d, e}$ & $40^{f}, 39^{d}$ & 32.9 \\
\hline
\end{tabular}

Data from: $a$, Kato et al. (2004); b, Falsen et al. (2005); c, McBee (1954); $d$, this study (conventional methods used in acid production tests); e, Patel et al. (1980); f, Yang et al. (1990). and $C$. thermocellum based on its optimum temperature for growth. The optimum temperature for growth of strain $\mathrm{P}^{\mathrm{T}}$ was $37{ }^{\circ} \mathrm{C}$, compared with reported values of $50-55$ and $60{ }^{\circ} \mathrm{C}$ for $C$. straminisolvens and $C$. thermocellum, respectively. Strain $\mathrm{P}^{\mathrm{T}}$ differed from A. cellulolyticus by the latter's Gram-negative cell wall, and it did not form spores. Also, the new isolate was obligately anaerobic, whereas C. straminisolvens was able to grow aerobically. Although strain $\mathrm{P}^{\mathrm{T}}$ appeared to be affiliated to F. sanguinis (Falsen et al., 2005), $F$. sanguinis differed in that cells were non-spore-forming cocci, it had a much lower DNA G+C content of $32.9 \mathrm{~mol} \%$ and it was unable to ferment carbohydrates.

On the basis of the distant phylogenetic relationship with related taxa and physiological and biochemical traits, it was evident that the novel strain was a member of a new genus within clostridial cluster III. Therefore, we suggest that strain $\mathrm{P}^{\mathrm{T}}$ represents a novel species of a new genus, for which the name Saccharofermentans acetigenes gen. nov., sp. nov. is proposed.

\section{Description of Saccharofermentans gen. nov.}

Saccharofermentans (sac.cha.ro.fer.men'tans. Gr. n. sakchâr sugar; L. part. adj. fermentans fermenting; N.L. neut. n. Saccharofermentans sugar-fermenting). 
Cells are Gram-positive, non-motile and oval. Obligately anaerobic. No microaerophilic or aerobic growth occurs. The predominant cellular fatty acids are $\mathrm{C}_{15}$ components. Mesophilic $\left(20-42{ }^{\circ} \mathrm{C}\right)$ and grow at neutral $\mathrm{pH}$. Chemoorganotrophic. Oxidase and catalase are not produced. Inorganic nitrogen compounds such as $\mathrm{NH}_{4} \mathrm{Cl}$, $\left(\mathrm{NH}_{4}\right)_{2} \mathrm{SO}_{4},\left(\mathrm{NH}_{4}\right)_{2} \mathrm{HPO}_{4}$ and $\mathrm{KNO}_{3}$ do not serve as sole nitrogen sources. A few sugars are fermented. Cellulose is not degraded. Aesculin is hydrolysed but gelatin is not. The major fermentation products from glucose include acetate, lactate and fumarate. Sulfate is not reduced. The type species is Saccharofermentans acetigenes.

\section{Description of Saccharofermentans acetigenes sp. nov.}

Saccharofermentans acetigenes [a.ce.ti'ge.nes. L. n. acetum vinegar; N.L. suff. -genes (from Gr. v. gennaô to produce) producing; N.L. adj. acetigenes vinegar- or acetic acid-producing].

Morphology and general characteristics are as described for the genus. Cells are $0.6-0.9$ by $1.2-1.8 \mu \mathrm{m}$ in size. Optimal growth occurs at $37{ }^{\circ} \mathrm{C}$. The $\mathrm{pH}$ range for growth is 5.0-7.5 with optimum growth at $\mathrm{pH}$ 6.5. Acid is produced from Dglucose, D-fructose, aesculin, sucrose, starch, dulcitol, mannitol, inositol and adonitol. Cellobiose, lactose, melibiose, trehalose, amygdalin and erythritol are weakly fermented. Acid is not produced from L-arabinose, Dgalactose, maltose, D-xylose, glycogen, inulin, mannose, raffinose, rhamnose, ribose, salicin, sorbose or sorbitol. No acid is produced from methanol, ethanol, 1-propanol, citrate, fumarate, malate, succinate, malonic acid, hippurate, sodium gluconate, succinic acid, $\beta$-hydroxybutyric acid, phenylacetic acid, cellulose or xylan. Milk is not curdled. Urease, lecithinase, lipase and indole are not produced. Methyl red test is positive and Voges-Proskauer test is negative. Nitrate is not reduced. $\mathrm{No}_{2} \mathrm{~S}$ is produced from peptone or thiosulfate. The major cellular fatty acids are iso- $\mathrm{C}_{15: 0}$, anteiso- $\mathrm{C}_{15: 0}$ and iso- $\mathrm{C}_{14: 0} 3-\mathrm{OH}$. The $\mathrm{G}+\mathrm{C}$ content of the genomic DNA of the type strain is $55.6 \mathrm{~mol} \%$.

The type strain, $\mathrm{P}^{\mathrm{T}}\left(=\mathrm{JCM} 14006^{\mathrm{T}}=\mathrm{AS} 1.5064^{\mathrm{T}}\right)$, was isolated from an up-flow anaerobic sludge blanket reactor treating brewery wastewater.

\section{Acknowledgements}

We are grateful to Professor Wenying Zhuang, Chinese Academy of Sciences, for suggesting the genus and species name and Dr Yajun Song, Chinese Academy of Military Medical Sciences, for analysis of cellular fatty acids. This work was supported by the Xiamen Inspection-Quarantine Technology Center.

\section{References}

Chen, S. \& Dong, X. (2004). Acetanaerobacterium elongatum gen. nov., sp. nov., from paper mill wastewater. Int J Syst Evol Microbiol 54, 2257-2262.

Collins, M. D., Lawson, P. A., Willems, A., Cordoba, J. J., FernandezGarayzabal, J., Garcia, P., Cai, J., Hippe, H. \& Farrow, J. A. E. (1994). The phylogeny of the genus Clostridium: proposal of five new genera and eleven new species combinations. Int J Syst Bacteriol 44, 812-826.

Falsen, E., Collins, M. D., Welinder-Olsson, C., Song, Y., Finegold, S. M. \& Lawson, P. A. (2005). Fastidiosipila sanguinis gen. nov., sp. nov., a new Gram-positive, coccus-shaped organism from human blood. Int J Syst Evol Microbiol 55, 853-858.

Holdeman, L. V., Cato, E. P. \& Moore, W. E. C. (1977). Anaerobe Laboratory Manual, 4th edn. Blacksburg, VA: Virginia Polytechnic Institute and State University.

Hungate, R. E. (1969). A roll-tube method for cultivation of strict anaerobes. Methods Microbiol 3B, 117-132.

Kaneda, T. (1991). Iso- and anteiso-fatty acids in bacteria: biosynthesis, function, and taxonomic significance. Microbiol Rev 55, 288-302.

Kato, S., Haruta, S., Cui, Z. J., Ishii, M., Yokota, A. \& Igarashi, Y. (2004). Clostridium straminisolvens sp. nov., a moderately thermophilic, aerotolerant and cellulolytic bacterium isolated from a cellulosedegrading bacterial community. Int J Syst Evol Microbiol 54, 2043-2047.

Kumar, S., Tamura, K., Jakobsen, I. B. \& Nei, M. (2001). MEGA2: molecular evolutionary genetics analysis software. Bioinformatics 17, 1244-1245.

Liu, W. T., Chan, O. C. \& Fang, H. H. (2002). Characterization of microbial community in granular sludge treating brewery wastewater. Water Res 36, 1767-1775.

Marmur, J. (1961). A procedure for the isolation of deoxyribonucleic acid from microorganisms. J Mol Biol 3, 208-218.

Marmur, J. \& Doty, P. (1962). Determination of the base composition of deoxyribonucleic acid from its thermal denaturation temperature. J Mol Biol 5, 109-118.

McBee, R. H. (1954). The characteristics of Clostridium thermocellum. J Bacteriol 67, 505-506.

Miller, L. T. (1982). Single derivatization method for routine analysis of bacterial whole-cell fatty acid-methyl esters, including hydroxy acids. J Clin Microbiol 16, 584-586.

Patel, G. B., Khan, A. W., Agnew, B. J. \& Colvin, J. R. (1980). Isolation and characterization of an anaerobic, cellulolytic microorganism, Acetivibrio cellulolyticus gen. nov., sp. nov. Int J Syst Bacteriol 30, 179-185.

Sasser, M. (1990). Identification of bacteria by gas chromatography of cellular fatty acids, Technical Note 101. Newark, DE: MIDI Inc.

Thompson, J. D., Gibson, T. J., Plewniak, F., Jeanmougin, F. \& Higgins, D. G. (1997). The CLUSTAL_X windows interface: flexible strategies for multiple sequence alignment aided by quality analysis tools. Nucleic Acids Res 25, 4876-4882.

Yang, J. C., Chynoweth, D. P., Williams, D. S. \& Li, A. (1990). Clostridium aldrichii sp. nov., a cellulolytic mesophile inhabiting a wood-fermenting anaerobic digester. Int J Syst Bacteriol 40, 268-272.

Zehnder, A. J. B. (1978). Ecology of methane formation. In Water Pollution Microbiology, pp. 349-376. Edited by R. Mitchell. New York: Wiley. 